\title{
CONTROL OF POTATO TUBER MOTH, PHTHORIMAEA OPERCULELLA (LEPIDOPTERA: GELICHIIDAE) IN RUSTIC FARM STORAGE AND FIELD BY MEANS BIOLOGICAL AND CULTURAL PRACTICES.
}

\author{
GABER, NEVIEN M., K. A. HASSAN and NAHLA A. EZZ
}

Plant Protection Research Institute, ARC, Giza, Egypt

(Manuscript received 16 August 2011)

\begin{abstract}
The present work was conducted in Qalubyia Governorate during 2010 to control the potato tuber moth, Phthorimaea operculella (Zeller) (Lepidoptera: Gelichiidae) in rustic farm storage and potato fields. Results showed that, double release of the parasitoid, Trichogramma evanescens Westwood and the predators, Chrysoperla carnea (Stephens) and Orius albidipennis (Reuter) were effective as biological agents against $P$. operculella under straw-cover heaps. The highest reduction percentage occurred with application of both $T$. evanescens and C. carnea, they reduced the infestation to $75.56 \%$ whereas application of both $T$. evanescens and 0 . albidipennis reduced the infestation to $56 \%$. Application of $O$. albidipennis alone gave poor reduction percentage $(5.1 \%)$. One release of 0 . albidipennis reduced the infestation to $21 \%$ in the field. However, application the agronomic cultural practices reduced rate of infestation to $45 \%$ at the trail end in the storge.
\end{abstract}

\section{INTRODUCTION}

Potato tuber moth (PTM), Phthorimaea operculella (Zeller) is the single most significant insect pest of potato in North Africa and the Middle East (Fuglie et. al., 1992). It is a noxious pest of potato in both field and store causing serious economic damage. The greatest damage occurs in storage where the larval mining of tubers causes rotting and renders the tubers and become unmarketable (Kroschel \& Koch 1994). In Egypt, a common method of tubers storage is to pile potatoes in strawcovered heaps under field conditions. According to (Von Arx et. al., 1987) PTM infestations may destroy the entire crop within 2-4 months in rustic stores.

The parasitoid, Trichogramma evanescens Westwood is a potential natural enemy of potato tuberworm as well as the predator, Chrysoperla carnea (Stephens) (Zaki, 1986 and Mandour et. al., 2008). Also, members of the genus Orius are a generalist predators of small arthropods associated with a wide range of natural and agricultural habitats (Vacante et. al.,1997). Furthermore, Orius albidipennis (Reuter) has tremendous potential as a biological control agent, especially in its native range around the Mediterranean Basin (Sobhy et. al., 2010). 
Cultural control in potato crop are equally important as the biological control (Horne \& Page, 2008). It can reduce $P$. operculella infestation in the field (Shelton and Wyman, 1979 c.a. Susannah et. al., 2009). The present work was carried out to control the potato tuber moth in both field and traditional storage, with application of biological agent and cultural practices.

\section{MATERIALS AND METHODS}

\section{Trichogramma evanescens}

The local egg parasitoid, T. evanescens was reared on Angoumois grain moth, Sitotroga. cerealella (Oliv.) eggs according to Abd El-Hafez (1994). Releases of $T$. evanescens were made using thick paper cards (Duplex paper, 250 weight) containing parasitized S. cerealella eggs. Each card contained 3 cohorts with parasitoids (500/each), thus, the total number of parasitoids/ card was about 1500 parasitoids.

\section{Chrysoperla carnea}

The predator maintained from laboratory rearing at $27 \pm 1^{\circ} \mathrm{C}$ and a photoperiod of $16: 8 \mathrm{~h}(\mathrm{~L}: \mathrm{D})$. The adults were placed in plastic boxes $(22 \times 13 \times 10 \mathrm{~cm})$ covered with black muslin for deposited eggs and changed every 2 days. Semi artificial diet ( $2 \mathrm{~g}$ yeast extracet, $1 \mathrm{~g}$ fractoze and $1 \mathrm{~cm}$ distilled water) drops were provided on tape stacked on the muslin. The dposited eggs were collected daily and kept in glass jars until hatching. The hatch larvae were supplied by eggs of $S$. cerealella as food source. The eggs used for rearing recycling were allowed to be deposited on black muslin, whereas the release, eggs were on black canson paper, subsequently cut in cylinder bands displaying 250 eggs/ each.

\section{Orius albidipennis}

O. albidipennis were reared at laboratory conditions of $28 \pm 2^{\circ} \mathrm{C}, 75 \pm 10 \% \mathrm{RH}$ and 16:18 h L.D. photoperiod. The adults were placed in plexiglass cylinders $(9 \mathrm{~cm}$ high $\times 4 \mathrm{~cm}$ diameter) covered with fine cotton gauze. Frozen eggs of Ephestia kuehniella Zeller (obtained from the stock culture of "Chrysoperla carnea Mass Rearing Unite" Faculty of Agriculture, Cairo Univ. Giza, Egypt) were used as a food source. Middle veins of lettuce were used as oviposition substrates. Veins of lettuce with Orius eggs were removed from the adult unites three times per week and placed in boxes $(15 \times 33 \times 10 \mathrm{~cm})$. To prevent cannibalism some strips of paper were added to each box and water was supplied by adding moist cotton. The $3^{\text {rd }}$ nymphal instar was employed. 


\section{Sitotroga cerealella}

Eggs of grain moth $S$. cerealella were collected from the $S$. cerealella mass production unites of bollworm department, Plant Protection Research Institute, Agricultural Research Center according to the method of Hassan (1995).

\section{Agronomics approach}

Recent study was conducted at Qalubyia governorate on potato from 2010 summer season crop and stored at piles in straw-covered heaps and in potato fields under field conditions. The experiments were performed under rustic farm store conditions, while the agronomic approach trial was followed out under recommended culture practices. The additional pre and post-harvesting practices in this trial were:

- Removing the potato vines and destroyed it before harvesting is an essential step in potato production.

- Removing of tubers with vascular discoloration as attackable source.

- Careful check for damaged and infected tubers and discard it (first check).

- Clean rice straw covering is significant factor when placing potatoes in storage.

- Impermeable check 15 days after storage (second check) for discarding the blighted tubers.

Total 450 plants from nine replicates (50 plants each/ 2 carats) were sampled from pre-harvesting potatoes twice a week intervals. Post-harvesting trial had five potato straw-covered heaps (one cubic meter in diameter/ each) and 100 potato tubers were randomly sampled from each cubic meter repeatedly till the crop selling. Check control was access as likely as experiment trial.

\section{Release}

Storage trials contain five potatoes straw-covered heaps (one cubic meter in diameter/ each). One of card T. evanescens, one of C. carnea cylinder band or 500 nymphs of $O$. albidipennis was hand placed on each heap under straw covers. The releasing agents were transported to the field in a cooling box. Two releases of beneficial species were followed out in each treatment. The stored tubers while received the two releases during the crop checkout to removing infested and diseased tubers 2 weeks intervals. Additional five heaps were set up as check control. One hundred potato tubers randomly sampled from each cubic meter (500 tubers/ treatment), repeatedly till the crop selling. One disperse (500 nymphs/ replicate) of $O$. albidipennis was carried out in potato fields at the end of April. Nine replicates (2 carats/ each) were installed in both treated and untreated potato fields. A total of 450 plants were examined for infestation status in both treated and untreated replicates.

Tuber infestation percentages were recorded and reduction percentages were calculated according to Henderson and Tilton (1955) equation. 


\section{RESULTS AND DESCUSSION}

Results in table 1 showed relative rates of tuber damage due to $P$. operculella ranked between (3.00-29.00\%). The highest infestation rates of this pest were recorded last season at the same locality, it being $4.00 \%$ (Ezz \& Hassan, 2010).

Double releases of the parasitiod, $T$. evanescens and the predators $C$. carnea and $O$. albidipennis were employed for tuberworm suppression in straw-covered heaps. Compared with check control, the most effective utilization of biological control agents was observed with $T$. evanescens and $C$. carnea integrated. The pest infestation reduced, reached to $74.71 \%$ after first release and $75.56 \%$ at the end of experiment (Table 1).

As shown in Table 1, reduction percentage at attempting end was $56.00 \%$ in $T$. evanescens and $O$. albidipennis combined use. Dramatically regression in reduction percentages were demonstrated till it reached $5.10 \%$ with 0 . albidipennis solo assigning. Through the field dispersal, this percentage was approximately $21.00 \%$ after a single release of $O$. albidipennis (Table 2).

Exact cultural practice treatments recorded $45.00 \%$ reduction in the PTM infestation rates at the trail end (Table 1).

From aforementioned results, combined utilization of $T$. evanescens and $C$. carnea resulted height reduction in P. operculella population. Ezz and Hassan (2010) recorded reduction rates 41.41 and $53.13 \%$ in tuberworm populations with single application of both $C$. carnea and $T$. evanescens, respectively. It has become common practice to apply several biocontrol agents simultaneously however against just one pest species (Madadi, et. al., 2008). In the combined use of natural enemy species, additive predation effects may explain the efficacy of natural enemy communities in suppression of herbivore populations (Rosenheim, 2005). We assumed that, if the previous two beneficial species are used simultaneously for $P$. operculella biological control it would contribute to suppress the tubers infestation under storage in strawcovered heaps.

The rostrum of our observation that, revealed $T$. evanescens may be an efficient apparatus to the tuberworm, whereas 0 . albidipennis showed weak preying behavior under rustic store trial. The predatory bug has tremendous potential as a biological control agent, especially in its native range around the Mediterranean basin. Nevertheless, little is known for the effect of the different preys on development of 0 . albidipennis compared with other species of Orius (Sobhy et. al., 2010). Predominantly, polyphagous integrated used could participate to reducing preys. 
Table 1. Reduction percentages of Phthorimaea operculella infestation under release three beneficial species in storage and cultural control compared with check

\begin{tabular}{|c|c|c|c|c|c|c|c|c|c|}
\hline \multirow[b]{2}{*}{ Sampling } & \multicolumn{5}{|c|}{ Treatment infestation \% } & \multicolumn{4}{|c|}{ Reduction \% } \\
\hline & $\begin{array}{c}\text { T. evanescens + } \\
\text { Ch. carnea }\end{array}$ & $\begin{array}{l}\text { T. evanescens + } \\
\text { O. albidipennis }\end{array}$ & $\begin{array}{c}0 . \\
\text { albidipennis }\end{array}$ & $\begin{array}{l}\text { Culture } \\
\text { practice }\end{array}$ & $\begin{array}{l}\text { Check } \\
\text { control }\end{array}$ & $\begin{array}{l}\text { T. evanescens } \\
+ \text { Ch. carnea }\end{array}$ & $\begin{array}{c}T . \\
\text { evanescens + } \\
0 . \\
\text { albidipennis }\end{array}$ & $\begin{array}{c}0 . \\
\text { albidipennis }\end{array}$ & $\begin{array}{l}\text { Cultural } \\
\text { control }\end{array}$ \\
\hline Sample 1 ( $1^{\text {st }}$ release) & 12.00 & 20.00 & 17.00 & 8.00 & 22.00 & & & & \\
\hline Sample 2 (week after release) & 4.00 & 11.00 & 5.00 & 7.00 & 29.00 & 74.71 & 58.28 & 77.69 & 33.62 \\
\hline Sample 3 ( $2^{\text {nd }}$ release) & 4.00 & 8.00 & 8.00 & 15.00 & 26.00 & 51.11 & 66.15 & 60.18 & 0.00 \\
\hline Sample 4 (before crop selling) & 2.00 & 6.00 & 11.00 & 3.00 & 15.00 & 75.56 & 56.00 & 5.10 & 45.00 \\
\hline
\end{tabular}


Table 2. Reduction percentages of Phthorimaea operculella infestation under release of $O$. albidipennis in the field compared with check control.

\begin{tabular}{|c|c|c|c|c|c|}
\hline \multirow{2}{*}{ Sampling } & \multicolumn{3}{|c|}{ Treatment infestation \% } & \multicolumn{2}{c|}{ Reduction \% } \\
\cline { 2 - 6 } & O. albidipennis & $\begin{array}{c}\text { Cultural } \\
\text { control }\end{array}$ & $\begin{array}{c}\text { Check } \\
\text { control }\end{array}$ & $\begin{array}{c}\text { Cultural } \\
\text { O. albidipennis }\end{array}$ \\
\hline Sample 1 (release) & 4.22 & 2.00 & 3.33 & & \\
\hline Sample 2 & 3.33 & 0.67 & 3.33 & 21.05 & 0.00 \\
\hline
\end{tabular}

Santi \& Maini (2006) mentioned that, if $O$. laevigatus and $C$. carnea are used for biological control simultaneous in greenhouses, they will only contribute.

Recent study conducted suppression in the $P$. operculella damage mainly to controlled agronomic cultural practices. In our case, we assume decline the infestation rates referable to strict agronomic practices especially narrowly tubers checkout period and removing the infested tubers after harvesting and under storage. Many cultural practices which used by farmers to improve the yield and quality of potato can also limit the infestation of PTM and minimize damage to tubers (Fuglie et. al., 1992 and Hanafi, 1999). However, further research needs to be done on dispersing the examined beneficial insects in cultural practices treatments to complement information on their successful application against potato tuberworm under storage.

\section{REFERENCES}

1. Abd EL-Hafez, A. 1994. Effectiveness of Trichogramma evanescens Westwood and Trichogramma bactrae Nagaraja in parasitizing eggs of Pectinophora gossypiella (Saund.) and Earias insulana (Boisd). Egypt. J. Biol. Pest. Control, 4(1): 113-120.

2. Ezz, N. A. and K. A. Hassan. 2010. Release of Chrysoperla carnea (Stephens) and Trichogramma evanescens Westwood for controling the potato tuber moth Phthorimaea operculella (Zeller) (Lepidoptera: Gelichiidae) in traditional storage. Bull. Ent. Soc. Egypt, Econ. Ser., 36: 1-6.

3. Fuglie, K., H. Ben Salah, M. Essamet, A. Ben Temime and A. Rahmouni 1992. The development and adoption of integrated pest management of the potato tuber moth, Phthorimaea operculella (Zeller) in Tunisia. Insect Sci. Appl., 14(4): 501-509.

4. Hanafi, A. 1999. Integrated pest management of potato tuber moth in field and storage. Potato Research, 42: 373-380.

5. Hassan, S. A. 1995. Improved method for the production of the Angoumois grain moth, Sitotroga cerealella (Oliv.). Trichogramma and other egg parasitoids Conference, Cario, Egypt, October 4-7, 1994, 157-160. 
6. Henderson, C. F. and E. W. Tilton. 1955. Tests with acaricides against the brown wheat mite, J. Econ. Entomol., 48:157-161.

7. Horne, P. and J. Page. 2008. Integrated pest management dealing with potato tuber moth and all other pests in Australian potato crops. http://www.vgavic.org.au/research and development/Researchers PDFs/ipm ap proach to potato crops.htm.

8. Kroschel, J. and W. Koch. 1994. Studies on the population dynamics of the potato tubermoth in the republic of Yemen. Journal of Applied Entomology, 118: 327-341.

9. Madadi H., A. Enkegaard, H. F. Brødsgaard, A. Kharrazi-Pakdel, A. Ashouri and J. Mohaghegh-Neishabouri. 2008. Orius albidipennis (Heteroptera: Anthocoridae): Intraguild predation and prey preference for Neoseiulus cucumeris (Acari: Phytoseiidae) on different host plants Entomol. Fennica., 19: 2-9.

10. Mandour N. S., M. F. Mahmoud, M. A. Osman and B. QIU. 2008. Efficiency, intrinsic competition and interspecific host discrimination of Copidosoma desantisi and Trichogramma evanescens, two parasitoids of Phthorimaea operculella. Biocontrol Science and Technology, 18 (9): 903 - 912.

11. Rosenheim J. A. 2005. Interaguild predation of Orius tristicolor by Geocoris spp. and the paradox of irruptive spider mite dynamics in California cotton. Biol. Cont., 32: 172-9.

12. Santi, F. and S. Maini. 2006. Predation upon Adalia bipunctata and Harmonia axyridi eggs by Chrysoperla carnea larvae and Orius albidipennis adults. Bulletin of Insectology, 59 (1): 53-58, 2006.

13. Sobhy, I., A. Sarhan, A. Shoukry, G. El-Kady, N. Mandour and S. Reitz 2010. Development, consumption rates and reproductive biology of Orius albidipennis reared on various preys. BioControl, 55(6): 753-765.

14. Susannah, G. C., D. S. Douches, K. Zarka and E. J. Grafius. 2009. Enhanced resistance to control potato tuberworm by combining engineered resistance, avidin, and natural resistance derived from, Solanum chacoense. Am. J. Pot. Res., 86: 24-30.

15. Vacante, V., G. E. Cocuzzap, D. E. Clercq, M. Van DE Veire and L. Tirry. 1997. Development and survival of Orius albidipennis and $O$. laevgatus (Het.: anthocoridae) on various diets. Entomophaga, 42 (4): 493-498.

16. Von Arx, R., J. Goueder, M. Cheikh and A. B. Temime. 1987. Integrated control of potato tubermoth Phthorimaea operculella (Zeller) in Tunisia. Insect Sci. Appl., 8: 989-994.

17. Zaki, F. N. 1986. On the rearing of the aphid lion, Chrysoperla carnea Steph. (Neuroptera, Chrysopidae) on artificially paralized prey. Journal Anzeiger für Schädlingskunde. 59: (2) 34-36. 


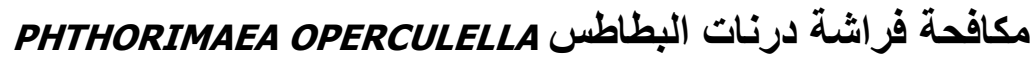 تحت ظروف التخزين التقليدية و الحقل باستخدام (LEPIDOPTERA: GELICHIIDAE) وسائل مكافحة حيوية وزراعية
}

\author{
نفين محمود جابر، كارم أبو زيد حسن ، نهلة عبد العزيز عز \\ معرج بحوث وقاية النباتاتـ مركز البحوث الزرراعية- الدقي- الجيزة- مصر
}

أجريت الدراسة الحالية في محافظة القليوبية لدكافحة فراثة درنات البطاطس

Phthorimaea operculella (Zeller) Trichogramma evanesceens للبطاطس و في الحقل. و كانت إطلاقتان من طفيل البيض وزيض

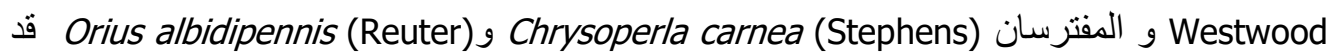
الطلتا ضد الآفة تحت ظروف تخزين درنات البطاطس علي هيئة أكوام مغطاة بقش الأرز. أظهرت

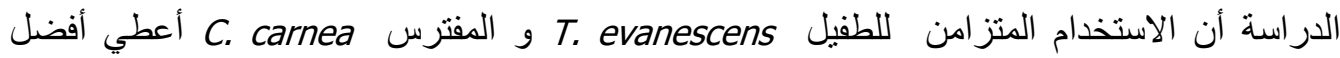

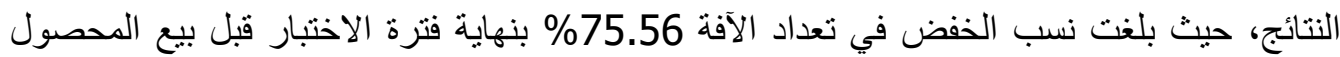

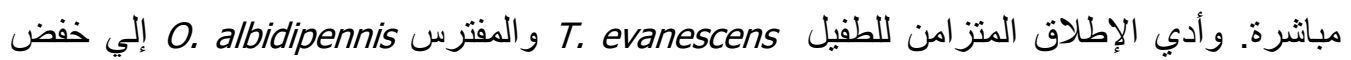

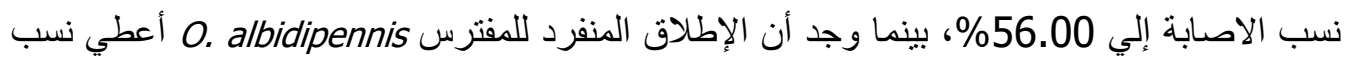

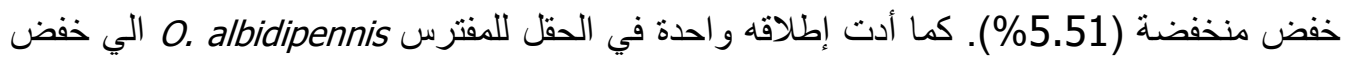

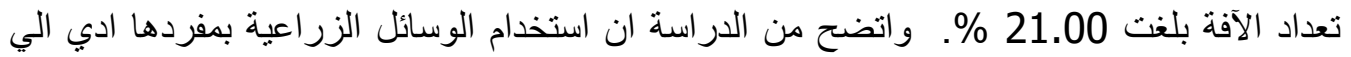
خفض تعداد فراشة درنات البطاطس تحت ظروف النخزين بنسبة بلغت 45.00 \% في نهاية فترة

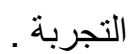

